\title{
A Simple Method for Assessment of Age-Related Changes in Physical Properties of Facial Dermal Papilla and Fibrous Structures*
}

\author{
Koji Mizukoshi, Kenya Hirayama \\ ** POLA Chemical Industries, Inc.
}

\begin{abstract}
Most age-related changes that appear on the surface of facial skin are caused by changes within the skin. Therefore, analyzing the internal state of the skin could make it possible to provide evidence-based counseling, which could offer benefits to customers. However, it is difficult to perform simple analyses of the inner condition of the skin, and conventional methods of analysis generally require costly laboratory equipment. Therefore, we used multiple regression analysis to create an estimation formula to calculate the skin's inner structure feature values based on skin surface feature values, which can be easily obtained. As objective variables, we used the number of dermal papillary structures and a score for dermal fibrous structure clearness. As explanatory variables, we used the feature values for sulci cutis and crista cutis characteristics, color characteristics, and frequency characteristics, as calculated from data including skin images. The concordance rate between corresponding before- and after-scores obtained with our novel estimation formula and the actual scores based on measured values for the number of dermal papilla structures was $100 \%$ and that for the clearness of dermal fibrous structures was $95 \%$. These results demonstrate that skin surface feature values, which can be obtained using a simple device such as a microscope, can be used to estimate the condition of the inner structures of the skin, including the number of dermal papillary structures and the clearness of dermal fibrous structures.
\end{abstract}

Key words : dermal papilla, dermal fibrous structure, aging, simple method, estimation formula for skin inner structure, skin's inner structure feature, skin surface feature, multiple regression analysis, facial skin, evidence-based counseling

\footnotetext{
* Received, October 19, 2016; Accepted, February 24, 2017

** 560, Kashio-cho, Totsuka-ku, Yokohama 244-0812, Japan
}

doi.org/10.5107/sccj.51.219

(C) 2017 The Society of Cosmetic Chemists of Japan 


\title{
顔面の真皮乳頭突起構造および 真皮線維状構造の簡便計測法の開発*
}

\author{
水越興治, 平山賢哉 \\ **ポーラ化成工業株式会社 横浜研究所
}

\begin{abstract}
顔面皮膚表面に現れる老化状態の多くは皮膚内部状態の変化が原因で表出する。そのため, 皮膚内 部状態の分析は, エビデンスに基づいたカウンセリングにつながり顧客ベネフィットとなる。一方 で, 従来の皮膚内部状態の分析は高価な研究用機器の使用が一般的であり, 簡便な分析が困難であつ た。そこでわれわれは, 容易に取得できる皮膚表面の特徵量から, 皮膚内部構造の特徵量を算出する 推定式の作成を重回帰分析で試みた。目的変数として真皮乳頭突起構造の数と線維状構造の鮮明性に 対するスコアを用いた。説明变数には皮膚画像などから算出された皮溝皮丘特性, 色特性および周波 数特性に関する特徵量を用いた。作成した推定式を用いて算出した推定スコアと実測值から得た実測 スコアを比較した結果, 真皮乳頭突起構造の数については, 対応するスコア前後のスコアを含む一致 率が 100\% となった。真皮線維状構造の鮮明性については, 対応するスコア前後のスコアを含む一致 率が 95\%となった。以上の結果より，マイクロスコープのような簡便な機器で得られる皮膚表面の 特徵量から, 真皮乳頭突起構造の数や真皮線維状構造の鮮明性といった皮膚の内部構造の状態が推定 できることが示された。
\end{abstract}

\section{1. 緒言}

視覚的および触感的に認識される加齢に伴うシワ，たる み, ハリのなさといった形態変化や, くすみといった皮虞 色変化などに代表される顔面皮膚の老化変化は，皮膚内部 構造の加齢に伴う変化によって引き起こされると考えられ る。

コラーゲンやエラスチンからなる真皮線維状構造は, 皮

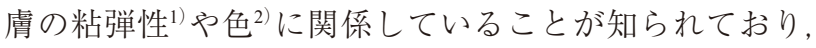
その加齢変化を知ることは美容上重要である。たとえば, 光老化部位ではソーラエラストーシスが生じ3) 線維束構造 が崩壊すること ${ }^{1)}$, 加齢によりコラーゲン分子の直径が変 化すること4)，などが知られている。また，真皮一表皮間 の凹凸構造である真皮乳頭突起構造も肌の色や粘弾性に関

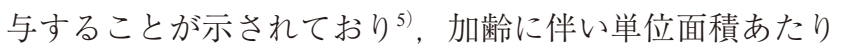
の数が減少することや, 突起構造の高さが低くなり断面積 が増加することも示されている6)。さらに真皮乳頭突起構 造は, 酸素や二酸化炭素などの代謝に関係する毛細血管と 一致して存在するため》代謝への寄与が考えられる。した がって, 加齢により変化する真皮線維状構造や真皮乳頭突

*2016.10.19 受付, 2017.2.24 採用

** $\overline{2} 244-0812$ 横浜市戸塚区柏尾町 560
起構造の状態を計測・分析し，その情報をもとにカウンセ リングや適切なスキンケアを行うことは美容や抗老化に捛 いて重要である。

皮膚の内部構造の計測は, 古くは直接的に組織切片を用 いるなど侵襲的な検討が主流であったが，近年は非侵襲的 に計測する機器が発達し，侵襲計測が容易ではない顔面皮 膚の研究にも広く活用されている。これまでにin vivo 共 焦点レーザー顕微鏡（CLSM）を始めとして，マルチフォ トン顕微鏡 ${ }^{8}$ や第 2 高調波発生光 $(\mathrm{SHG} \text { 光 })^{9)}$, 光干渉断層 像（OCT），超音波測定装置などの多様な物理現象を利用 し, 直接的に皮膚内部構造からのシグナルを得て計測を行 う機器が開発されている。このような機器を用いて真皮乳 頭突起構造(6) や真皮線維状構造 ${ }^{100}$ の特徵量が定量的に計測 され，年齢や皮膚の見た目との関連性も明らかにされてき た。

一方で，これらの機器を用いた計測では，被験者は仰臥 位等で安静にする必要があり, デー夕取得にも一定時間を 要するため被験者への負担が大きい。また，計測機器は一 般に高価であり, 計測結果である画像などから特徴量を数 值として導出するための解析処理も必要である。そのた め, 多くの化粧品ユーザーを対象に日常的に計測・分析に 基づいた皮膚内部の老化状態の情報を提供することは困難

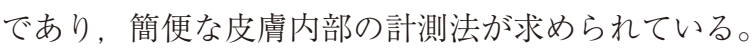


皮膚内部の状態を簡便に計測するには，皮膚表面に現れ ている特徴から推定する方法が考えられる。皮膚の内部構 造と表面には関係性があることがさまざまな研究から示さ れており 1),2).5), この関係性を用いることで, 皮膚表面の 情報から皮膚内部構造が推定できると考えられる。すなわ ち, 皮膚表面の物性の特徵量を数值化し多変量解析で数学 的に皮膚内部構造との関係性を数式化することで, 皮膚内 部の構造が推定できると考えられる。

皮膚表面の物性の特徵量化については，近年のビデオマ イクロスコープなどの電子デバイスの発達により, 皮膚表 面画像を容易かつ安価に取得でき, またその画像から PC を用いて簡便に特徵量を抽出することが可能となってい る。たとえば画像中の色の特徴に対しては, 各種表色系に おける強度や標準偏差を用いて算出するこができる。ま た，空間周波数解析などにより画像の濃淡や周期性に関す る特徵量を計算することができる。色以外においても，小 林らが11) 皮膚表面画像から皮溝皮丘などの構造の状態を 100 種類程度の特徵量で表現してキメスコアを算出してお り, 皮膚表面のさまざまな形状に関する特徵量の抽出も可 能となっている。

そこで今回, 多変量解析を用いた検討により, 真皮乳頭 突起構造や真皮線維状構造といった皮虐内部構造の特徽量 を，ビデオマイクロスコープなどの汎用機器で取得できる 皮膚表面の皮溝皮丘や色情報から簡便に推定する方法につ いて検討を行った。

\section{2. 実験}

\section{1. 被 験 者}

データ・セット $1 ： 20$ 代から 60 代の各世代 18 名, 合計 90 名の関東在住の日本人女性を被験者とした。

データ・セット2：20 代 5 名, 30 代 4 名, 40 代 3 名,

50 代 5 名, 60 代 5 名の合計 22 名の関東在住の日本人女性 を被験者とした。

今回実施したヒトを対象としたすべての試験は，ポーラ 化成工業株式会社内の倫理委員会にて審査，承認の上実施 した。またすべての被験者のインフォームドコンセントを 得た上で実施した。

\section{2. 計測 部 位}

本検討では，すべての計測において，㚘部分 $1 \mathrm{~cm}$ 四方 の内側（Fig.-1）を計測領域とした。

\section{3. 皮膚計測}

CLSM (Vivascope1500Plus ; Lucid, Henrietta, NY, USA) を用いて皮膚内部を計測した。CLSM で計測される 1 視野 の大きさは一辺が $500 \mu \mathrm{m}$ の正方形である。計測は, 皮膚 の深さ方向に $3 \mu \mathrm{m}$ 刻みで, 真皮層である $180 \mu \mathrm{m}$ の深さ

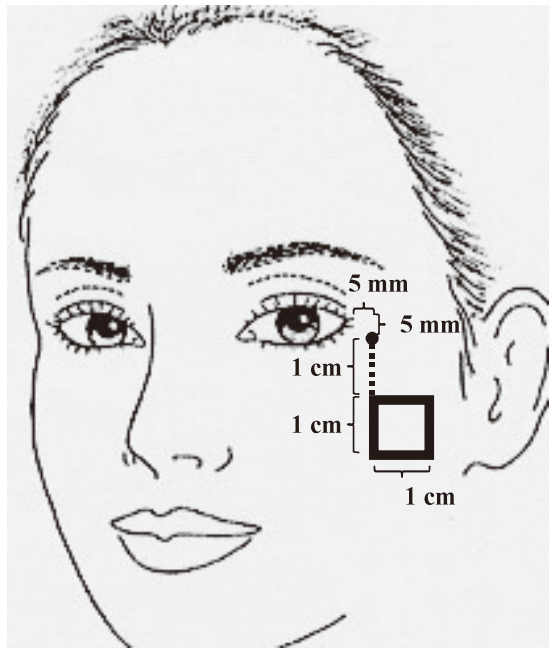

Fig.-1 Facial measurement sites.

The area in the $1 \mathrm{~cm}^{2}$ of the cheek shown in the image was the measurement target.

まで計測した。水平方向には，4 視野四方 $(2 \mathrm{~mm}$ 四方) で計測し，その中から最も毛包構造が少ない連続した 2 視 野四方（1 mm 四方）を選択して解析対象平面とした。

同一部位に対して，皮膚表面のデジタル画像をビデオマ イクロスコープ (i-scope, Moritex, Tokyo, Japan）で 30 倍の レンズを用いて撮影した。画像サイズは $640 \times 480$ pixels サイズであり，スケールを用いて実測した 1 視野の撮影面 積は $10.15 \times 7.62 \mathrm{~mm}$ であった。皮膚色の計測には分光測 色計（CM-2600d； Konicaminolta, Tokyo, Japan）を用いて 行い，HVC 表色系，Lab 表色系の值を算出した。

\subsection{CLSM を用いた皮膚内部構造の特徵量の定量化}

CLSM で得られた皮膚内部の画像を用い単位面積あたり の真皮乳頭突起構造の個数および，真皮の線維状構造の鮮 明性をおのおの特徵量として定量化した。詳細は先行研 究6), 10) を参照されたいが，以下簡単に記載する。

真皮の線維構造の鮮明性については，まず定量化を行う 解析平面の深さを設定した。CLSM で皮膚の深さ方向に画 像を系列的に採取した際に，真皮領域において線維構造が はっきり見えていた状態からさらに深部に向かって計測し ていくと，線維構造が不鮮明となっていくが，不鮮明とな る深さより $12 \mu \mathrm{m}$ 表皮側に戻った平面を解析平面とし た。線維構造の鮮明性は, 線維構造のはっきり度合いや線 の太さ，線間の距離を基準としてスコア化（Fig.-2a）を 行った。設定した解析平面に対し, 専門評価者 3 名でスコ ア評価を行いその平均值を用いた。小数点以下については 四捨五入を行った。

真皮乳頭突起構造の個数の定量化については, Fig. $-2 b$ に示す代表的画像を判別規準として，真皮乳頭突起構造の 
a)

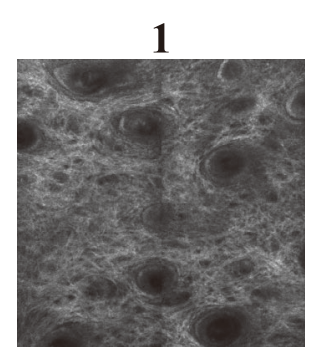

High
2

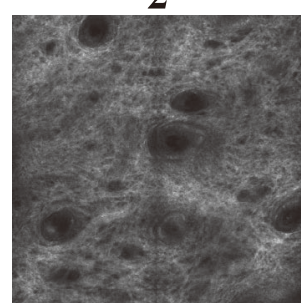

3

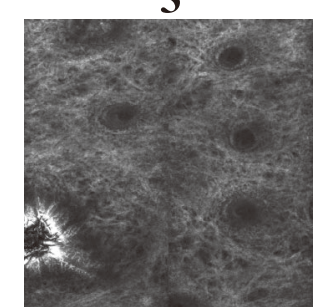

4

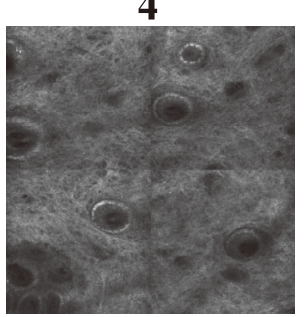

5

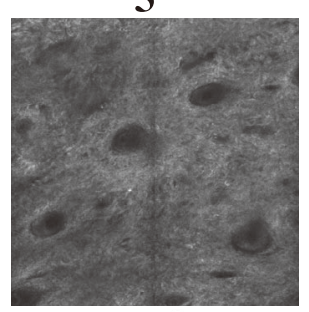

Low

\section{Clearness}

b)

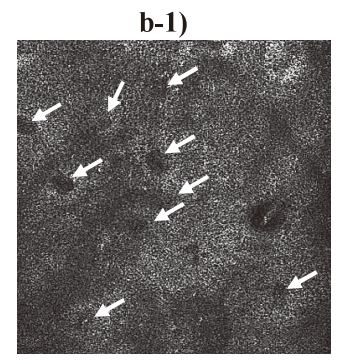

b-2)

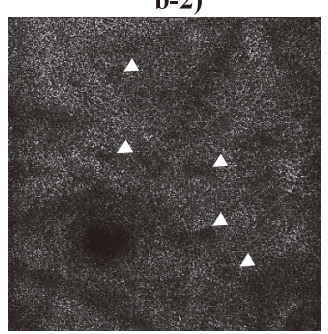

Fig.-2 a) Score criteria for clearness of dermal fibrous structures. The 1-5 score system was used, with a score of 1 indicating a dermal fibrous structure with a high degree of clearness and 5 indicating a dermal fibrous structure with such minimal clearness that it appeared to have been blocked out. See the previous study ${ }^{10)}$ for details on scoring. b) Extraction standards for dermal papillary structures. b-1) The standard CLSM images of dermal papillary structures for inclusion. A dermal papilla structure was employed in the analysis if the inner part of a donut-like circular structure had clear contrast compared to surrounding area (white arrow), b-2) The standard CLSM image of a dermal papillary structure for exclusion. A dermal papilla structure was excluded if the contrast of circular structure was less compared to the surrounding area than for b-1 (white arrow head). See the previous study $^{6}$ for details on extraction standards for dermal papillary structures.

抽出を行った。乳頭構造と考えられるリング状形状の輝度 差が周囲と明瞭なもの (Fig. - 2, b-1, 白矢印) を解析対象 として抽出した。一方で, その特徵が弱いもの（Fig.-2, b-2, 白矢印頭）は今回の解析対象からは除外した。その 後単位計測面積あたりに存在する真皮乳頭突起個数を計測 した。

いずれの皮膚内部構造の計測においても，計測領域にシ ミや開大した毛穴がある被験者およびアトピー性皮膚炎の 可能性がある被験者は解析対象から除外した。

\section{5. ビデオマイクロスコープ画像を用いた皮膚表面特 徵量抽出}

ビデオマイクロスコープで取得した画像を用い, 皮溝皮 丘に関する特徵量および周波数特性に関する特徵量を抽出 した。

皮溝皮丘に関する特徵量は, 十字二值化一短直線マッチ ング法 ${ }^{11)}$ により算出した。本法は, 線形状を抽出すること に適した十字二值化法により画像を二值化して線形状を抽
出したのち, 線形状に対して特定の長さの短直線を当ては め, 当てはめられた短直線の本数や角度, 重なりなどか ら, 画像中に存在する皮溝の本数や方向性，太さなどの特 徵量を算出する方法である。算出に供した画像および短直 線の条件を以下に示す。取得した画像の解像度 $(640 \times 480$ pixels）は $736 \times 552$ pixels（1.15 倍）に変換した。また画 像中で使用した短直線の長さは 5 pixels, 太さは 1 pixels と した。

画像の周波数特性については空間周波数を用いた方 法 $^{10)}$, 12) を用いて算出した。取得した画像の解像度 $(640 \times$ 480 pixels）を $736 \times 552$ pixels（1.15 倍）に変換し， 1024 pixels 四方の被験者の平均皮膚色をもつレイヤー上に貼り 付け, グレースケールに変換した。1024 pixels 四方の画像 の一辺の 2 倍である 2048 pixels の大きさの周波数を 1 cycle, 画像の一辺 2048 pixels を 1/1024にした大きさ（2 pixels） の周波数を 1024 cycle と定義し， 1 から 125 cycleにかけて の空間周波数の解析を行うことにより cycleごとの強度を 
計算した。

以上の抽出した各特徴量について, 対数や乗数, 逆数な どの算術を加え合計 580 個のパラメータを作成した。

\section{6. 皮膚表面特徵量を用いた皮膚内部構造に対する推 定式の作成}

ビデオマイクロスコープ画像や分光測色計から得られる 皮膚表面特徵量を用いて, 真皮乳頭突起構造の単位面積あ たりの個数および真皮線維状構造の鮮明性を算出する推定 式を作成した。検討には JMP Ver.9（SAS institute, Cary, USA） を用いた。

推定する皮膚内部構造（目的変数）は，データ・セット 1 の CLSM 画像から算出された真皮乳頭突起構造の個数を 対数化した数值, および真皮線維状構造の鮮明性をスコア 評価した值 ${ }^{6)}$, 10) を用いた。説明変数は, ビデオマイクロス コープ画像や分光測色計から算出された皮膚表面の特徵量 に関する計測值および被験者の実年齢を設定し，ステップ ワイズ法を用いた重回帰分析を行った。説明変数となるパ ラメータの選別にはAIC (Akaike’s Information Criterion) 法による変数増減法条件を用いた。

データ・セット 1 を用いて作成した推定式の精度の検証 には，データ・セット 2 の皮膚表面の特徵量および皮膚内 部構造值を用い，推定值と実測值の一致率を算出した。

\section{3. 結果}

\subsection{CLSM を用いた皮膚内部構造の特徵量の定量化 とその加齢傾向}

CLSM を用いた皮膚内部構造の計測結果を以下に示す。 データ・セット 1 を用いた, 加齢に伴う単位面積あたり の真皮乳頭突起構造の個数の变化を検討した結果 ${ }^{6)}$ を Fig.3a に示す。被験者 90 名中, 計測領域にシミや開大した毛 穴がある被験者およびアトピー性皮膚炎の可能性がある被 験者を除外した 77 名を計測対象とした。単位面積あたり の乳頭突起構造の個数は被験者間で $0 \sim 60$ 個のバリエー ションがあり，加齢に伴い減少することが示された。本検 討結果から, 乳頭突起構造の個数に基づいた 4 段階のスコ ア值を 77 名の分布がおおむね正規性をとる值となるよう に score 1（36 個〜), score 2（11～35 個), score 3（1～10 個） およびscore 4（0 個）を設定した。データ・セット 1 およ びデータ・セット 2 のスコアごとの被験者数を Fig. $-3 \mathrm{~b} に$ 示す。

データ・セット 1 を用いた, 加齢に伴う真皮線維状構造 の鮮明性スコア值の変化を検討した結果 ${ }^{10)}$ を Fig. $-4 \mathrm{a}$ に示 す。真皮乳頭突起構造の計測対象となった被験者と同一の 77 名を計測対象とした。真皮線維状構造の鮮明性は加歯令 とともに低下することが示された。またデータ・セット 1 a)

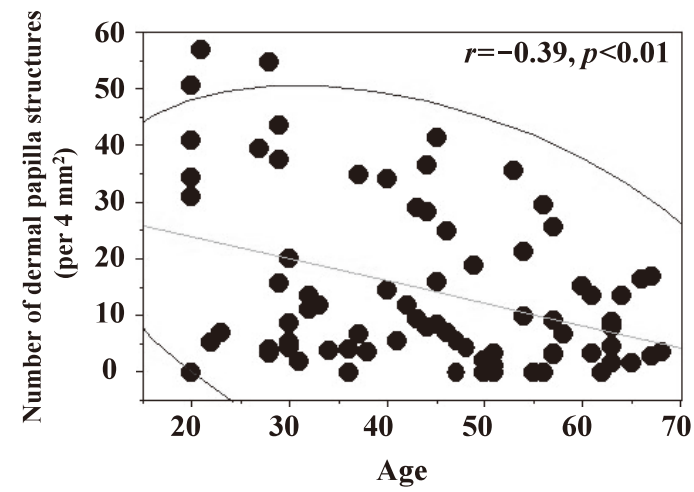

b)

Score 1 : More than 36

Score $2: 11-35$

Score $3: 1-10$

Score $4: 0$

\begin{tabular}{|c|c|c|c|c|c|}
\hline \multicolumn{2}{|c|}{} & \multicolumn{4}{|c|}{ Score } \\
\cline { 3 - 6 } \multicolumn{2}{|c|}{} & $\mathbf{1}$ & $\mathbf{2}$ & $\mathbf{3}$ & $\mathbf{4}$ \\
\hline \multirow{3}{*}{ Number of subjects } & Data set 1 & 8 & 35 & 24 & 10 \\
\cline { 2 - 6 } & Data set 2 & 0 & 10 & 5 & 2 \\
\hline
\end{tabular}

Fig.-3 a) Age-related changes in the number of dermal papillary structures per unit of area using data set 1. b) Scores as classified by the number of dermal papillary structures per unit of area, and the number of subjects falling into each score class for data sets 1 and 2 .

The circle depicts a $95 \%$ probability ellipse. The correlation coefficient was calculated using Pearson's product-moment correlation coefficient.

とデータ・セット 2 の鮮明性スコアごとの被験者数を Fig. $-4 b$ に示す。

3.2. ビデオマイクロスコープ画像および分光測色計を 用いた皮膚表面特徵量の定量化とその加齢傾向

データ・セット 1 のビデオマイクロスコープ画像に対し て行った十字二值化一短直線マッチング法, 空間周波数お よび分光測色計を用いて抽出した特徵量の值の分布はおお むね正規分布であった（data not shown）。各特徴量と年齢 との相関性は, 十字二值化一短直線マッチング法を用いた 皮膚表面の皮溝皮丘に関する特徵量のうち，解析画像内で の皮溝 (短直線) の密度の分散を示す特徴量 ${ }^{11)}$ のみが相関 係数 $0.25(p<0.05)$ 程度の弱い相関を示した。また, 空 間周波数の特徽量においても，8および 10 cycleの強度の み年齢と $0.25(p<0.05)$ 程度の弱い相関性を示した。分 光測色計から得られる皮膚については, H（色相）と C（彩 度）がそれぞれ $0.6(p<0.01)$ と $0.39(p<0.05)$ の正の相 
a)

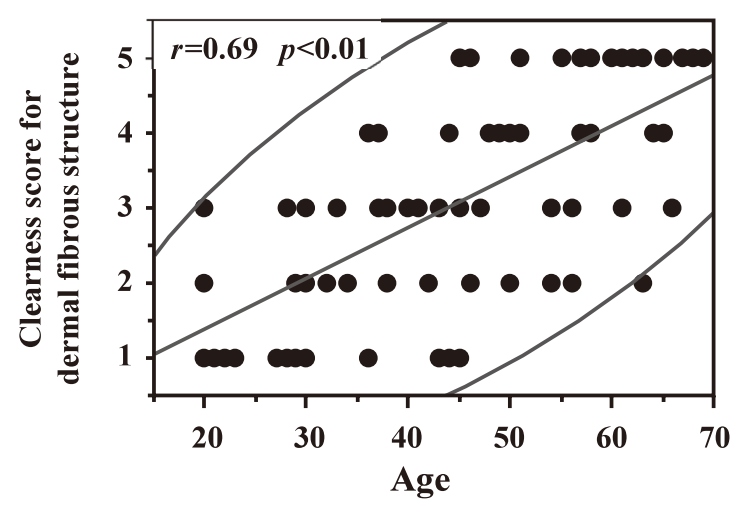

b)

\begin{tabular}{|c|c|c|c|c|c|c|}
\hline \multicolumn{2}{|c|}{} & \multicolumn{6}{|c|}{ Score } \\
\cline { 3 - 7 } & $\mathbf{1}$ & $\mathbf{2}$ & $\mathbf{3}$ & $\mathbf{4}$ & $\mathbf{5}$ \\
\hline \multirow{3}{*}{ Number of subjects } & Data set 1 & 13 & 13 & 19 & 11 & 19 \\
\cline { 2 - 7 } & Data set 2 & 5 & 6 & 2 & 3 & 6 \\
\hline
\end{tabular}

Fig. -4 a) Age-related changes in the clearness of dermal fibrous structures for data set 1. b) The number of subjects falling into each score class for data sets 1 and 2 .

The circle depicts a $95 \%$ probability ellipse. The correlation coefficient was calculated using Pearson's rank correlation coefficient.

関を, $\mathrm{V}$ (明度) が-0.44 $(p<0.05)$ の負の相関性を示した。

\section{3. 皮膚表面特徵量を用いた皮膚内部構造に対する推 定式の作成}

データ・セット 1 より求めた, 単位面積あたりの真皮乳 頭突起構造の個数を対数化した值および真皮線維状構造の 鮮明性スコア值それぞれを目的変数にし，皮膚表面画像の 特徵量および年齢を説明変数に用いた重回帰分析を行った 結果, 説明変数として選定されたパラメータと係数, $t$ 值 を Table-1 および Table-2 に示す。また作成された推定式 より算出された推定值と実測值のプロットを Fig. -5 およ び Fig. -6 に示す。

単位面積あたりの真皮乳頭突起構造の個数に対する推定 式は，表に示す 14 個の説明変数から構成され，その自由 度調整済決定係数は 0.63 であった。また真皮線維状構造 の鮮明性に対する推定式は，13 個の説明線数から構成さ れ，その自由度調整済決定係数は 0.61 であった。

次にデータ・セット 2 を用い, 作成した単位面積あたりの 真皮乳頭突起構造の個数および真皮線維状構造の鮮明性に 対する推定式の推定精度の確認を行った。真皮乳頭突起構 造の個数の推定精度は, 実測值および推定式で算出される 推定值を，3.1. で記載した score 1（36 個〜), score 2（11〜
35 個）, score 3（1～10 個）, score 4（0 個）の 4 段階のス コア值に変換した值を用いて確認した。結果をおのおの Table-3, 4 に示す。スコア化した単位面積あたりの真皮乳 頭突起構造の個数については, 推定值と実測值が完全一致 する推定精度は $74 \%$ ，実測值に対応する推定值のスコア 前後のスコアまで許容した場合の推定精度は $100 \%$ であっ た。また真皮線維状構造の鮮明性については，完全一致の 推定精度 $50 \%$, 実測值に対応する推定值のスコア前後の スコアまで許容した場合の推定精度は $95 \%$ でることが 確認された。

\section{4. 考察}

今回われわれは，簡便な皮膚内部構造状態の分析技術開 発を目的として，ビデオマイクロスコープを代表とする皮 膚表面計測機器から得られる皮膚表面の特徽量を用い，皮 膚内部構造の特徵量を算出する推定式の確立を重回帰分析 を用いて試みた。

重回帰分析による推定式作成では，目的変数として設定 する皮膚内部構造の特徵量が定量的に数值化されているこ とが必要である。さらに皮膚内部構造の特徵量が，一般女 性が老兆として自覚できる粘弾性や皮膚色といった皮膚の 
Table-1 Estimation formula created through multiple regression analysis. Relationship between measured score and the estimation formula (predicted score) results for the number of dermal papillary structures per unit of area.

\begin{tabular}{|c|c|c|c|c|}
\hline \multirow{2}{*}{ Equation item } & \multicolumn{2}{|r|}{ Mean of equation item } & \multirow{2}{*}{ - Coefficient } & \multirow{2}{*}{$t$ Value } \\
\hline & Analytical method & Mean & & \\
\hline Y-intercept & - & Y-intercept of multiple regression equation & 7.42 & - \\
\hline $\log _{10}$ age & - & Logarithm of the subject's actual age & -5.07 & -5.06 \\
\hline $\mathrm{C}$ value of skin color & Spectrophotometer & $\mathrm{C}$ value of $\mathrm{HCV}$ color plane & 1.97 & 4.4 \\
\hline Value of 72 cycles & Spatial frequency & Value of 72 cycles & -10.92 & -4.4 \\
\hline Value of 37 cycles & Spatial frequency & Value of 37 cycles & 6.4 & 3.52 \\
\hline Value of 16 cycles & Spatial frequency & Value of 16 cycles & -3.26 & -3.36 \\
\hline $\begin{array}{l}\text { Reciprocal of kurtosis } \\
\text { for } 90^{\circ}-180^{\circ}\end{array}$ & $\begin{array}{l}\text { Short-line segment- } \\
\text { matching process- } \\
\text { ing }\end{array}$ & $\begin{array}{l}\text { Reciprocal value of kurtosis. Kurtosis is a histo- } \\
\text { gram shape of numbers of short-line seg- } \\
\text { ments for different angles, when a histogram } \\
\text { from } 90 \text { degrees to } 180 \text { degrees is regarded } \\
\text { as normal distribution }\end{array}$ & -21.5 & -3.18 \\
\hline $\mathrm{V}$ value of skin color & Spectrophotometer & V value of HCV color plane & 1.66 & 2.6 \\
\hline Value of 78 cycles & Spatial frequency & Value of 78 cycles & 5.29 & 2.41 \\
\hline Kurtosis & $\begin{array}{l}\text { Short-line segment- } \\
\text { matching process- } \\
\text { ing }\end{array}$ & $\begin{array}{l}\text { Kurtosis of a histogram of numbers of short-line } \\
\text { segments for different angles, when a histo- } \\
\text { gram from } 0 \text { degrees to } 180 \text { degrees is re- } \\
\text { garded as normal distribution }\end{array}$ & -1.24 & -2.35 \\
\hline $\begin{array}{l}\text { Square value for mod- } \\
\text { al width position }\end{array}$ & $\begin{array}{l}\text { Short-line segment- } \\
\text { matching process- } \\
\text { ing }\end{array}$ & $\begin{array}{l}\text { Square value for width at maximum value in } \\
\text { width histogram. Width is defined as short } \\
\text { line overlapping number to minor axis direc- } \\
\text { tion of short line }\end{array}$ & 0.039 & 2.27 \\
\hline $\begin{array}{l}\text { Reciprocal of kurtosis } \\
\text { for } 0^{\circ}-180^{\circ}\end{array}$ & $\begin{array}{l}\text { Short-line segment- } \\
\text { matching process- } \\
\text { ing }\end{array}$ & $\begin{array}{l}\text { Reciprocal value of kurtosis. Kurtosis is a histo- } \\
\text { gram of numbers of short-line segments for } \\
\text { different angles, when a histogram at } 0 \text { de- } \\
\text { grees to } 180 \text { degrees is regarded as normal } \\
\text { distribution }\end{array}$ & -0.015 & -1.91 \\
\hline $\begin{array}{l}\text { Reciprocal of maxi- } \\
\text { mum frequency in } \\
\text { latter half }\end{array}$ & $\begin{array}{l}\text { Short-line segment- } \\
\text { matching process- } \\
\text { ing }\end{array}$ & $\begin{array}{l}\text { Reciprocal value of maximum number in more } \\
\text { than } 95 \text { degrees in a short-line segment angle } \\
\text { histogram }\end{array}$ & 1770.31 & 1.66 \\
\hline Value of 60 cycles & Spatial frequency & Value of 60 cycles & 1.14 & 0.54 \\
\hline $\begin{array}{l}\text { Reciprocal for stan- } \\
\text { dard deviation of } \\
\text { sulcus cutis density } \\
\text { variance }\end{array}$ & $\begin{array}{l}\text { Short-line segment- } \\
\text { matching process- } \\
\text { ing }\end{array}$ & $\begin{array}{l}\text { Reciprocal value of standard deviation of sulcus } \\
\text { cutis density variance. Sulcus cutis is defined } \\
\text { as the ratio of short-line area to the measure- } \\
\text { ment area }\end{array}$ & 13.12 & 0.47 \\
\hline
\end{tabular}

老化の原因となることが重要である。先行研究の結果か

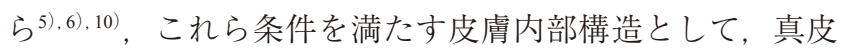
乳頭突起構造㧍よび真皮線維状構造を検討対象として選定 した。今回の推定式作成では特徵量の中から, 真皮乳頭突 起構造の存在程度を示す最も基本的な特徵量であると考え られる単位面積あたりの個数を, 今回の検討対象として採 用した。真皮線維状構造についても, 線維束構造が崩壊す ること1)やソーラエラストーシスが発生すること ${ }^{13)}$ が知ら れており, それらを反映する線維状構造の鮮明性が加齢と
ともに低下することがCLSM を用いた検討で定量的に示 されている ${ }^{10)}$ 。また，皮膚の老化兆候との関係では，それ ら変化が皮膚色の変化 ${ }^{2)}$ や粘弾性 ${ }^{11}$ に関与することが示さ れている。以上のことから, 鮮明性を今回の検討対象とし て採用した。

目的変数となる皮膚内部構造と同様に, 説明変数として 設定する皮膚表面の特徵量も定量的な数值データとして確 保する必要がある。皮膚表面の特徵量は大きく形状的な特 徵と色の特徵の 2 つが考えられ, 形状的特徽としては皮溝 
Table-2 Estimation formula created through multiple regression analysis. Relationship between measured score and the estimation formula (predicted score) results for the clearness of dermal fibrous structures. The straight line in the figure indicates "measured values = estimated values."

\begin{tabular}{|c|c|c|c|c|}
\hline \multirow{2}{*}{ Equation item } & \multicolumn{2}{|r|}{ Mean of equation item } & \multirow{2}{*}{ - Coefficient } & \multirow{2}{*}{$t$ Value } \\
\hline & Analytical method & Mean & & \\
\hline Y-intercept & - & Y-intercept of multiple regression equation & 0.5 & - \\
\hline $\mathrm{Age}^{15}$ & - & The subject's actual age to the 15 th power & 0.0074 & 7.47 \\
\hline Modal width position & $\begin{array}{l}\text { Short-line segment- } \\
\text { matching process- } \\
\text { ing }\end{array}$ & Width at maximum value in width histogram & -0.55 & -3.19 \\
\hline $\begin{array}{l}\text { Maximum connectivi- } \\
\text { ty number }\end{array}$ & $\begin{array}{l}\text { Short-line segment- } \\
\text { matching process- } \\
\text { ing }\end{array}$ & Maximum connectivity number of short lines & 0.42 & 2.94 \\
\hline Kurtosis for $0^{\circ}-90^{\circ}$ & $\begin{array}{l}\text { Short-line segment- } \\
\text { matching process- } \\
\text { ing }\end{array}$ & $\begin{array}{l}\text { Kurtosis is a histogram of numbers of short-line } \\
\text { segments for different angles, when a histo- } \\
\text { gram from } 0 \text { degrees to } 90 \text { degrees is regard- } \\
\text { ed as normal distribution }\end{array}$ & 0.79 & 2.01 \\
\hline Value of 10 cycles & Spatial frequency & Value of 10 cycles & -2.06 & -2 \\
\hline Value of 50 cycles & Spatial frequency & Value of 50 cycles & 4.58 & 1.97 \\
\hline $\begin{array}{l}\text { Sulcus cutis width } \\
\text { variance }\end{array}$ & $\begin{array}{l}\text { Short-line segment- } \\
\text { matching process- } \\
\text { ing }\end{array}$ & Variance (variation) of sulcus cutis widths & -0.25 & -1.57 \\
\hline $\begin{array}{l}\text { Max value of sulcus } \\
\text { cutis density }\end{array}$ & $\begin{array}{l}\text { Short-line segment- } \\
\text { matching process- } \\
\text { ing }\end{array}$ & $\begin{array}{l}\text { Max value of sulcus cutis densities. Sulcus cutis } \\
\text { is defined as theratio of short-line area to the } \\
\text { measurement area }\end{array}$ & -0.35 & -1.3 \\
\hline Cube for width mode & $\begin{array}{l}\text { Short-line segment- } \\
\text { matching process- } \\
\text { ing }\end{array}$ & $\begin{array}{l}\text { Cube value for maximum value in width histo- } \\
\text { gram }\end{array}$ & $-4.28 \mathrm{E}-09$ & -1.21 \\
\hline Value of 35 cycles & Spatial frequency & Value of 35 cycles & -2.35 & -1.09 \\
\hline Value of 44 cycles & Spatial frequency & Value of 44 cycles & 3.27 & 1.09 \\
\hline Value of 1 cycle & Spatial frequency & Value of 1 cycle & 0.65 & 1.07 \\
\hline Value of 43 cycles & Spatial frequency & Value of 43 cycles & -2.23 & -0.8 \\
\hline
\end{tabular}

皮丘構造があげられる。従来, 皮溝皮丘構造の定量化は, スコア化 ${ }^{14)}$ や粗さパラメータによる解析 ${ }^{15}$ が主流であっ た。一方, 皮溝皮丘は高次構造をもち, 皮膚内部の構造変 化の状態を反映することが知られていることから ${ }^{16}$, 皮膚 内部構造の推定にはより詳細な特徵量化が必要である。そ こでわれわれは, 当てはめる短直線の本数, 短直線のつな がりおよび角度で，さまざまなスケールの構造を数值化で

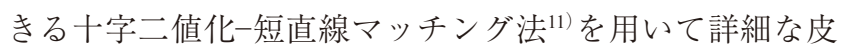
溝皮丘構造の抽出を行った。一方, 皮膚表面の色に関する 特徵には, 毛穴に代表される凹凸構造による陰影や皮膚色 のムラなどが存在する。そのような画像のうねりとして示 される皮膚の皮膚表面の特徵を抽出するために, 空間周波 数解析を用いた特徵量抽出を行った。さらに皮虐色に関す る特徴量については, 分光測色計から得られるスペクトル を元に Lab 值や HVC 值を算出した。
次に各特徵量を用いて皮膚内部構造を推定する式の作成 を試みた。多変量解析にはさまざまな方法があるが, 今回 の推定式作成では量的な説明変数を用いて量的な目的変数 の予測を行うために重回帰分析を行った。重回帰分析にお いては, 一般的に説明変数の数を増やすことで推定式作成 に用いた計測データとの適合性を高めることができるが， 過剩適合を起こしやすくなる。このため重回帰式作成時は パラメー夕数を抑える必要があり, 今回は AIC（Akaike's Information Criterion）法を用いて検討を行い17), AIC 值が 最小となるモデルに必要な説明変数を選択した。

真皮乳頭突起構造の単位面積あたりの個数に対する重回 帰式（推定式）を作成した結果，14個の説明変数から構 成され (Table-1), 自由度調整済決定係数は 0.63 であっ た。一般に決定係数は 0.5 以上で, 回帰式の当てはまりが よいとされて㧍り，実際作成された推定式より算出された 


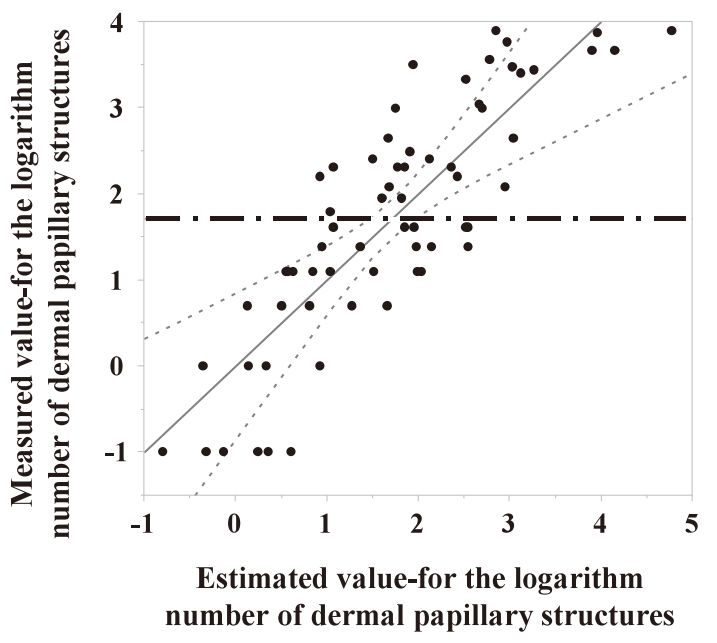

Fig.-5 Estimation formula created through multiple regression analysis.

Results of multiple regression analysis for the number of dermal papillary structures per unit of area. The straight line in the figure indicates "measured values $=$ estimated values." The dotted line indicates the $95 \%$ confidence interval (upper and lower limits). The chaine line indicates the average measured values.

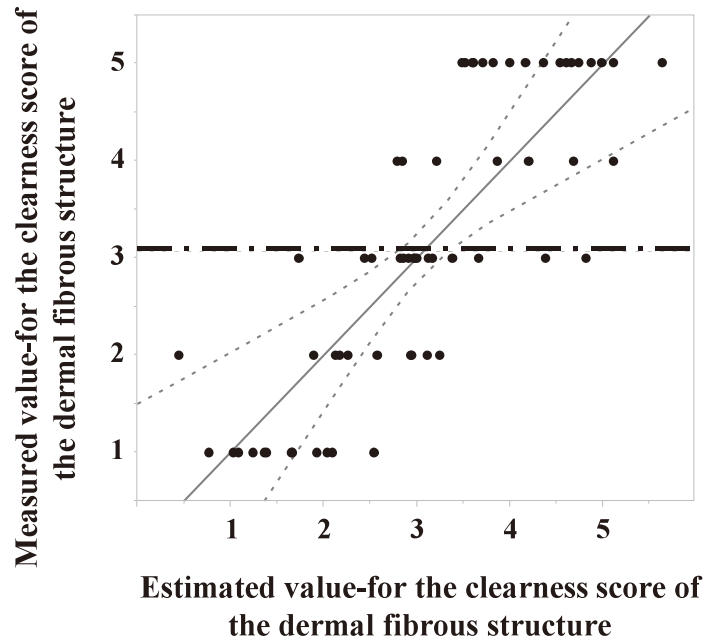

Fig.-6 Estimation formula created through multiple regression analysis.

Results of multiple regression analysis for the clearness of dermal fibrous structures. The straight line in the figure indicates "measured values $=$ estimated values." The dotted line indicates the $95 \%$ confidence interval (upper and lower limits). The chaine line indicates the average measured values.
Table-3 Verification of the accuracy of the estimation formula created using multiple regression analysis with new data (data set 2).

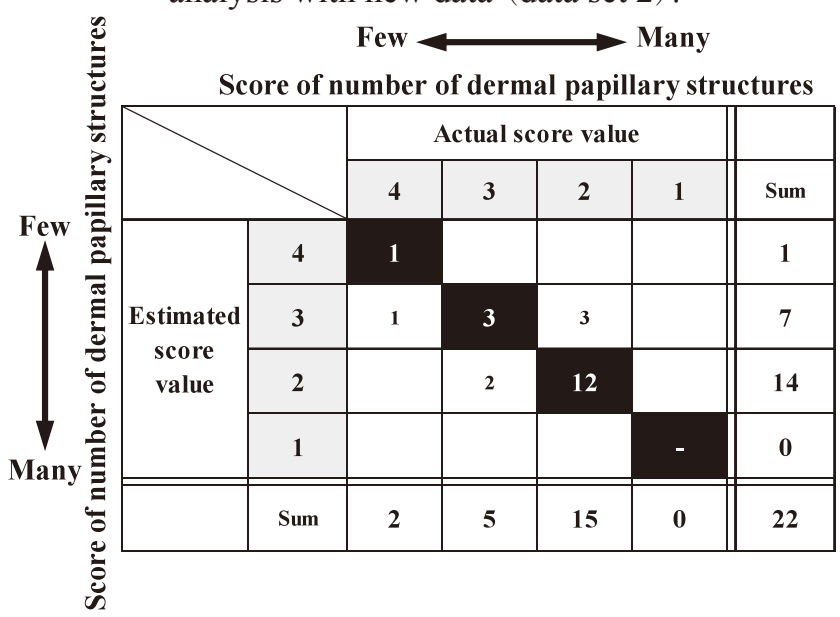

Accuracy of the estimation formula for the number of dermal papillary structures per unit of area.

Table-4 Verification of the accuracy of the estimation formula created using multiple regression analysis with new data (data set 2).
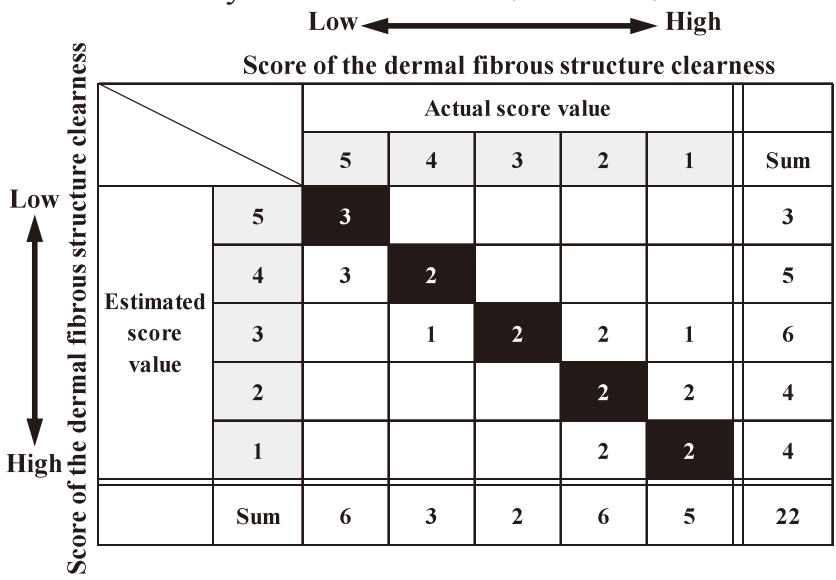

Accuracy of the estimation formula for the clearness of dermal fibrous structures.

推定值と実測值のプロット（Fig.-5）もよい対応を示して いることから，作成した推定式の当てはまりは良好といえ る。選択された説明変数のうち, 最も $t$ 值が大きい変数と しては年齢に関する值であった。皮膚の計測值としては, 皮膚色である $\mathrm{C}$ 值や $\mathrm{V}$ 值が選択され，また複数の周波数 成分の特徵量が選択された。先行研究から ${ }^{5)}$, 乳頭突起構 造の光の拡散性や皮膚色ムラへの寄与が示されており, こ の関係性から補色の関係性を示す特徵を持つ Lab 表色系 ではなく, 明るさや彩度といった特徴を示す HVC 表色系 の特徵量や周波数成分が説明変数として選択されていると 
推察できる。また説明変数としては短直線マッチング法の パラメータも選択された。真皮乳頭突起構造は角層の座屈 曲の出現しやすさと関係することが示されており ${ }^{18)}$ ，これ は皮溝皮丘として現れると考えられることから，短直線 マッチング法の特徵量はこの関係を反映して選択されたと 推察できる。

真皮線維状構造の鮮明性に対して作成した推定式におい ては, 13 個の説明線数から構成され (Table-2), その自由 度調整済決定係数は 0.61 であった。また実際作成された 推定式より算出された推定值と実測值のプロット（Fig.-6) もよい対応を示していることから, 本推定式も当てはまり が比較的高いといえる。選択された説明変数のうち, 最も $t$ 值が大きい変数としては年齢に関する值であった。皮膚 の計測值としては, 短直線マッチング法に関する特徵量が 選択され，次に周波数成分に関する特徴量が選択された。 短直線マッチング法の成分については, 皮膚内部の線維構 造の状態は皮溝皮丘と関係していることが考察されてお り ${ }^{19)}$ ，今回の結果もそれを反映して選択されていると推察 できる。また, 真皮線維マトリックス構造は光の拡散に重 要であることが示されており ${ }^{20)}$ ，この関倸性から周波数成 分も説明変数として選択されていると推察できる。

今回いずれの推定式の説明変数においても, 最も $t$ 值が 大きい変数は年齢に関する值であった。一方で，年齢のみ で真皮乳頭突起構造の単位面積あたりの個数や真皮線維状 構造の鮮明性について回帰式を作成した場合, 自由度調整 済決定係数は扮の扮の 0.1 と 0.4 程度であった（data not shown)。したがって年齢のみでは, 作成した推定式より 当てはまりが低く, 皮膚計測值が皮膚内部構造の推定には

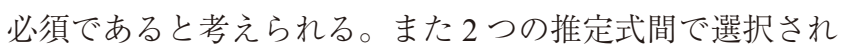
た説明変数に扔いて, 特に分光測色機の值の有無で違いが 生じた。より皮表表層に近い真皮乳頭突起構造の方が光の 拡散性に寄与しているからであると考察できる。

重回帰分析によって得られた真皮乳頭突起構造の単位面 積あたりの個数掞よび真皮線維状構造の鮮明性の推定式に 対して, 精度の確認を行った。この精度の確認において は，実際の顧客への情報提供では分析結果の良し悪しを久 コアで提示すること, また真皮線維状構造の鮮明性がスコ ア形式であることから, 真皮乳頭突起構造の個数も Fig.-3b に示す 4 段階のスコア值に変換して検討を行った。その結 果, データ・セット 2 に実測值スコア 1 の被験者が含まれ なかったものの, 真皮乳頭突起構造の個数については推定 式で算出した数值と実測值間の完全一致率が $74 \%$ あ り，対応するスコアの前後のスコアを含んだ場合の一致率 は 100\%であった（Table-3）。また，真皮線維状構造の鮮 明性に対しては, 完全一致率が 50\%であり, 対応するス
コアの前後のスコアを含んだ場合の一致率は $95 \%$ であっ た（Table-4）。以上の結果より，ビデオマクロスコープを はじめとして得られる皮膚表面の特徴量から, 真皮乳頭突 起構造の個数や真皮線維状構造の鮮明性といった皮膚の内 部構造の状態が正確に推定できることが示された。

本研究では, 単位面積あたりの真皮乳頭突起構造の個数 に対する推定式作成を行ったが，真皮乳頭突起構造につい ては，高さや断面積についても計測しておりの，また皮膚 表面物性との関連も推察できることから，これらに特徽量 に対する推定式の構築も可能であると考えている。また真 皮線維状構造についても, 今回示した鮮明性と同様に線維 状構造の方向性についても計測しており, 皮膚表面の皮溝 皮丘の流れなどに関連している可能性が考えられることか ら，鮮明性と同様に推定式の作成は可能であると考えてい る。また今回の検討では, 皮膚色を分光測色計から求めて いるが，ビデオマイクロスコープ画像を用いても色情報を 得ることは可能であり，ビデオマクロスコープ画像のみか ら皮膚内部構造を推定することができると考えられる。

\section{5. 結}

\section{論}

本研究で, 従来は専用の比較的高価な非侵襲計測機を用 い, 計測から数值導出までの解析処理が複雑である手順を ふむことでしか分析することができなかった皮膚の内部構 造状態を，簡便かつ安価なデバイスにより，皮膚表面の特 徵量から推定できることを示した。今後もデバイステクノ ロジーの進歩により，汎用的に得られる顧客の顔や皮膚の 情報は増加していくと考元られる。今回示したような特徵 量の数理的解析や現在発展している深層学習のような手法 を取り入れることで, 研究所などの専門機関でなければ提 供できなかった顔や皮膚の情報を，多くの化粧品ユーザー に届けることが可能になると考えられる。

\section{引用文献}

1) Y. Nishimori, C. Edwards, A. Pearse, K. Matsumoto, M. Kawai, R. Marks, J. Invest. Dermatol., 117, 1458-1463 (2001)

2) Y. Nishimori, A. D. Pearse, C. Edwards, R. Marks, Skin Res. Technol., 4, 79-82 (1998)

3) E. C. Naylor, R. E. Watson, M. J. Sherratt, Maturitas, 69, 249-256 (2011)

4) M. C. Branchet, S. Boisnic, C. Frances, C. Lesty, L. Robert, Archiv. Gerontol. Geriat., 13, 1-14 (1991)

5) K. Mizukoshi, T. Nakamura, A. Oba, Skin Res. Technol., 22, 295-304 (2016)

6) K. Mizukoshi, K. Yonekura, M. Futagawa, T. Nakamura, K. Hirayama, K. Takahashi, Skin Res. Technol., 21, 224-231 
(2015)

7) K. A. Pasyk, S. V. Thomas, C. A. Hassett, G. W. Cherry, R. Faller, Plast. Reconstr. Surg., 83, 939-945 (1989)

8) T. H. Tsai, S. H. Jee, C. Y. Dong, S. J. Lin, J. Dermatol. Sci., 56, 1-8 (2009)

9) 平尾哲二, 江川麻里子, 山下豊信, 表面科学, 35, 1722 (2014)

10) K. Mizukoshi, K. Hirayama, Skin Res. Technol., 23, 312$320(2017)$

11）小林 宏, 橋本卓弥, 山崎和広, 平井義和, 日本機械 学會論文集 C 編，76，922-929（2010）

12) S. Inoue, K. Hirayama, K. Yamazaki, Tech. Rep. IEICE, $100,15-22(2001)$

13) V. Werth, X. Shi, E. Kalathil, C. Jaworsky, Photochem. Photobiol., 63, 308-313 (1996)
14）木村知史，山本美恵子，堀野政章，金田泰雄，粧技 誌，25, 87-109 (1991)

15）林 照次, 三村邦雄，西島 靖，粧技誌，23，43-54 (1989)

16）今山修平, 日本美容皮膚科学会雑誌, 13, 138-145(2003)

17）坂元慶行, 石黒真木夫, 北川源四郎, 情報量統計学, 共立出版, 1983

18）桑水流理，サウトン・ジャリヤポーン，吉川暢宏，生 産研究, 59, 124-127（2007）

19）今山修平, 皮膚科診療最前線シリーズ スキンケア最 前線，宮地良樹編，メディカルレビュー社， 2008, p. $120-123$

20) H. Kim, J. Baek, J. Eo, K. Choi, M. Shin, J. Koh, Skin Res. Technol., 21, 41-46 (2015) 